HARSHITA BHATNAGAR* - VINAY V. MISHRA **

\title{
ISP Liability for Third Party Copyright Infringement: A Comparative Analysis for Setting International Standard Norms
}

\begin{abstract}
The rapid expansion of the Internet has greatly expanded the context in which copyright infringement can occur. ISPs largely remain the gateway through which end users access the vast flow of digital content traveling throughout cyberspace. Unfortunately, ISPs are at the receiving end of many disputes involving IPR violations. The difficulty in pinpointing the real culprit has resulted in a situation where the ISP is often taken to the court.

The paper examines such situations where the ISPs have been involved into litigations for third party copyright infringement across the globe. An attempt has been made to highlight the problems in such litigations and how it has affected the industry. An analysis has been made of all the laws passed by the legislations of various countries which has created a limit in the liability of ISPs in various countries if the ISP follows certain guidelines. Special emphasis has been given to the decisions of the courts of these countries after the creation of such limitations and an analysis has been done of whether such exceptions have infact served the purpose or not. Finally the paper is concluded with the basic purpose and theme of the paper which is to create an international standard guideline and in doing so the point that the individual countries legislations wont have an effective control over the problem has been highlighted and this is the reason why an international body like WIPO and WTO has to enter to control the situation.
\end{abstract}

Keywords: ISP, copyright infringement, internet, DMCA, copyright, internet service providers

\section{Introduction}

Copyright law aims to balance the competing policy goals of encouraging creativity and allowing public access to information. ${ }^{1}$

B.A. LL.B (Hons.), Gujarat National Law University, Gandhinagar, India

E-mail: xyzvinay@gmail.com

** B.A. LL.B, Gujarat National Law University, Gandhinagar, India

E-mail: xyzvinay@gmail.com

1 See Weinstock-Netanel, N.: Asserting Copyright's Democratic Principles in the Global Arena. Vanderbilt Law Review, 51 (1998) 217, 220. This balance is particularly important and difficult when it concerns the Internet, where meaningful copyright protection must exist in order to promote further intellectual development in the Internet 
The Internet with which we are all familiar is a gigantic network of computer networks. The amazing capability of the Internet to promote the exchange of knowledge, information, and ideas on a universal scale has surely revamped the way people interact. It has been due to the internet that knowledge capital has been able to be communicated to others and recognized.

The rapid expansion of the Internet, however, greatly expanded the context in which copyright infringement can occur. The Internet, with its inexpensive access, quick downloads and forwarding capabilities allow users to effortlessly bypass copyright laws at a substantial cost to legitimate users.

The Internet Service Providers ${ }^{2}$ have played a very important role in the development of the Internet. Even as the Internet continues to evolve, ISPs largely remain the gateway through which end users access the vast flow of digital content traveling throughout cyberspace. Unfortunately, ISPs are at the receiving end of many disputes involving IPR violations. The difficulty in pinpointing the real culprit has resulted in a situation where the ISP is often taken to the court. The courts of United States and some other countries have confronted this issue since the early nineties. In 1996, The World Intellectual Property Organization ${ }^{3}$ concluded negotiations to introduce new rules and clarify existing rules in order to provide adequate solutions to the questions raised by new economic, social, cultural and technological developments. Subsequent to this, various countries like United States, Australia, Singapore, India along with some other countries have enacted legislations in this regard.

This article reflects upon the evaluation of the legal environment of these countries and concludes with the proposal to set an international standard norm.

and failing to provide protection would lead to a reduction in the incentive to create and less material available for public use. Therefore, it is important that copyright owners are protected and compensated for infringements occurring over the Internet. See Mercurio, B.: Internet Service Provider Liability for Copyright Infringements of Subscribers: A Comparison of the American and Australian Efforts to Combat the Uncertainty. Murdoch University Electronic Journal of Law, 9 (2002) 51.

2 Hereinafter referred to as 'ISP'.

3 The World Intellectual Property Organization (Hereinafter referred to as 'WIPO'.) is a specialized agency of the United Nations. It is dedicated to developing a balanced and accessible international intellectual property system, which rewards creativity, stimulates innovation and contributes to economic development while safeguarding the public interest. WIPO was established by the WIPO Convention in 1967 with a mandate from its Member States to promote the protection of IP throughout the world through cooperation among states and in collaboration with other international organizations. Its headquarters are in Geneva, Switzerland. See "What is WIPO"; Accessed from http://www.wipo.int/about-wipo/en/what_is_wipo.html 


\section{What is an ISP?}

Before examining the liability of ISP it becomes essential to have a brief examination of ISP. These are companies or corporations that enable clients to connect to the Internet. Just as in any other business, ISPs may range from conglomerates to small companies having only a handful of clients. Typically, an ISP provides its clients with more than just an email account and access to the web; it offers facilitation to upload files including web pages to the ISP's publicly accessible servers, enabling users to access these files. ${ }^{4}$

\section{The liability of ISPs - a controversial topic}

The liability of ISPs in cases of Copyright infringement is one topic which has generated lot of fiery debate throughout the globe. The legislation of various countries and the case laws decided especially by the United States Courts helps in deciding the true position of ISP liability in today s era. It also becomes particularly necessary to limit the unlimited liability for ISPs in cases of copyright infringement.

While the Internet has helped artists, educators, researchers, and publishers explore and conquer their markets with their knowledge capital, the very same technology also makes it possible for copyright pirates to copy and distribute anything present on the Internet, while remaining both anonymous and undetectable. Copying is the easiest thing one can do on the Internet, and so has become a valid concern for IPR holders who urge that something be done quickly to address this menace. Identifying the individual who posts allegedly infringing material is not an easy task, whereas spotting a financially solvent ISP to impose liability can be the easiest and most obvious route for a copyright owner. With technical ability to close subscriber accounts, ISPs need to share with copyright owners the responsibility of curtailing and preventing infringement. Creating unified substantive international copyright law remains an impracticable solution to the mounting problem of global scale infringement. ${ }^{5}$

\footnotetext{
${ }^{4}$ Unni, V. K.: Internet service provider's liability for copyright infringement- how to clear the misty Indian perspective. Richmond Journal of Law and Technology, 8 (2002) 13.

5 Soma, J. T.-Norman, N. A.: International take-down policy: a proposal for the WTO and WIPO to establish international copyright procedural guidelines for internet service providers. Hastings Communications and Entertainment Law Journal, 22 (19992000) 391.
} 
The provisions for ISP liability in different parts of the world have been discussed below:

\section{A. The American perspective}

Before the enactment of the Digital Millennium Copyright Act ${ }^{6}$ 1998, relatively few cases determined the ISP liability in Copyright infringement cases. In 1998 , Congress adopted $\S 512$ of the DMCA, a legislative attempt to formalize structured immunities for ISPs, clarify the rights of copyright holders, and otherwise react to infringing content and conduct plaguing the Internet's new digital regime. ${ }^{7}$

\section{A.1. The historicalneed for ISP Immunity-The pre DMCA era}

The ease with which ISPs were brought into costly litigations for copyright infringement without any error on their part has created problems for the ISPs.

There are three theories under which ISPs are potentially liable for their subscribers' copyright infringement: direct, ${ }^{8}$ vicarious ${ }^{9}$ or contributory ${ }^{10}$ infringe-

'Hereinafter referred to as 'DMCA'.

7 The Constitution of United States authorizes Congress to establish a legislative scheme "to promote Science and the useful Arts, by securing for limited Times to Authors $\ldots$ the exclusive right to their ... writings..." See U.S. Const. art. 1, § 8, cl. 8. See Also, Hsieh, L.-McCarthy, J. M.-Monkus, E.: Intellectual; Property Crimes. American Criminal Law Review, 35 (1998) 899.

${ }^{8}$ A finding of direct copyright infringement is based on two factors: 1) the plaintiff's ownership of a valid copyright and 2) a defendant's violation of one of the plaintiff's exclusive rights. The 1976 Copyright Act imposes strict liability for direct copyright infringement, but knowledge is relevant to an award of statutory damages.

9 Although the Copyright Act does not expressly provide for vicarious liability, courts have consistently imposed vicarious liability when two factors exist-"the right and ability to supervise" the primary infringer and a "direct financial interest in the exploitation of copyrighted materials." See Alfred C. Y.: Internet service provider liability for subscriber copyright Infringement, enterprise liability, and the first amendment. Georgetown Law Journal, 88 (2000) 1833.

${ }^{10}$ To be liable for contributory infringement, the defendant must know of the activity constituting the infringement, and induce, cause, or materially contribute to it. See Sony Corp. v. Universal City Studios, Inc., 464 U.S. 417 (1984); Gershwin Publ'g Corp. v. Columbia Artists Mgt., Inc., 443 F.2d 1159 (2d Cir. 1971). 
ment. ${ }^{11}$ The pre-DMCA era was marked by cases addressing each type of liability, some of which have been discussed below:

\section{A.1.1. Playboy enterprises, inc. V. Frena-the beginning}

The very first case regarding an IPR violation committed on the Internet came in 1993. But the Playboy ${ }^{12}$ case, dealt with the liability of a Bulletin Board Service $^{13}$ operator, rather than that of an ISP. Fee-paying subscribers could upload and download photographs on the BBS. Playboy owned exclusive copyrights for many of these photographs. Frena claimed that it had not uploaded any of Playboy's images to the BBS and had removed those photographs from the BBS on becoming aware about it.

The court found the BBS operator liable for direct copyright infringement because it supplied a product containing unauthorized copies of a copyrighted work. It does not matter that defendant claims it did not make the infringing copies itself. ${ }^{14}$ This position was reaffirmed in Sega Enterprises Ltd. v. MAPHIA. ${ }^{15}$

\section{A.1.2. The Netcom decision: move toward safe harbors for ISPs}

A couple of years after Playboy case, a California federal court reached a different conclusion in Religious Technology Center v. Netcom On-Line Communications Services, Inc. ${ }^{16}$ In Netcom, a user posted copyrighted material of the Church of Scientology on a Usenet newsgroup that was connected to the Internet through the ISP. ${ }^{17}$

${ }^{11}$ Salow, H. P.: Liability immunity for internet service providers-how is it working? Journal of TechnologyLaw and Policy, 6 (2006) 1.

12 Playboy Enterprises, Inc. v. Frena, 839 F. Supp. 1552 (M.D. Fla. 1993).

${ }^{13}$ An electronic bulletin board ("BBS") consists of electronic storage media, such as computer memories or hard disks, which are connected to telephone lines by modem devices, and are controlled by a computer. Users of BBSs can transfer information from their own computers to the storage media on the BBS by uploading the information, or they can download information from the BBS onto their computers. See Sega Enterprises, Ltd. v. MAPHIA, 948 F. Supp. 923, 927 (N.D. Cal. 1996) ("Sega II”). [Hereinafter Bulletin Board Services is referred to as 'BBS'.]

${ }^{14}$ See Playboy Enterprises, Inc. v. Frena... op. cit. 1556. The court, citing the Copyright Act's strict liability standard, rejected the BBS operator's argument that it was unaware of the infringement.

\footnotetext{
${ }^{15} 857$ F. Supp. 679 (N.D. Cal. 1994).

${ }^{16} 907$ F. Supp. 1361 (N.D. Cal. 1995) (“Netcom”).

${ }^{17}$ Ibid. $1365-1366$.
} 
Because a finding of direct infringement would result in liability for every single Usenet server in the worldwide link of computers transmitting the infringing message to every other computer, the court held liability better resolved under "the rubric of contributory infringement," a scheme more capable of addressing the complex relationship between ISPs and subscribers ${ }^{18}$ and is made out if the ISP knew or should have known of the infringement and had substantially induced, caused, or contributed to that conduct. ${ }^{19}$ A claim of vicarious liability could be sustained where the right or ability to control the infringing conduct exists and financial benefit, directly attributable to the infringing content, accrues to the ISP. ${ }^{20}$

Unfortunately, from an academician's point of view, the case settled before trial. But, the decision in this case made it crystal clear that an act of volition is a prerequisite to copyright liability. This was surely good news for American ISPs.

A.1.3. Sega II case-a new approach by court to different theories of liability In Sega II, ${ }^{21}$ the same Netcom Court relying on its earlier decision in Netcom, again refused to find a BBS operator liable for direct infringement stressing that the BBS operator did not upload or download the infringing files himself and thus did not directly cause the copying. ${ }^{22}$ However the court found the BBS operator liable for contributory infringement because it knew that BBS subscribers were copying Sega's video games. ${ }^{23}$

${ }^{18}$ Ibid. 1369.

${ }^{19}$ Ibid. 1382

${ }^{20}$ See Bretan, J.: Harboring doubts about the efficacy of $\$ 512$ immunity under the DMCA. Berkeley Technology of Law Journal, 18 (2003) 43, 46. See also Hayes, D. L.: Copyright Liability of Online Service Providers. The Computer and Internet Law. 19 (2002) 15, 19. Although Hayes notes that at least one court relied on Netcom to establish no direct financial benefit where an ISP charged a flat fee for its services, Hayes suggests that the Netcom holding, which heavily relied on the district court ruling in Fonovisa, has been imperiled by subsequent findings. Namely, the Ninth Circuit's reversal on the issue of financial benefit in Fonovisa, Inc. v. Cherry Auction, Inc., 76 F.3d 259 (9th Cir. 1996) (establishing sufficient benefit to auction owners based on admission fees and concession sales) and a similar result in A\&M Records Inc. v. Napster, Inc., 239 F.3d 1004 (9th Cir. 2001) (establishing financial benefit based on the draw that infringing content has on users of the service) make any future reliance by ISPs on Netcom to establish no financial benefit a more risky proposition.

${ }^{21}$ Sega Enterprises Ltd. v. MAPHIA ; 948 F. Supp. 923, 927 (N.D. Cal. 1996).

${ }^{22}$ Ibid. 932.

${ }^{23}$ The BBS operator admitted that users were allowed to upload and download Sega games from his MAPHIA BBS. Moreover, evidence indicated that he tracked, or at least 


\section{A.2. The DMCA-the basic framework and application of $\S 512$}

The U.S. Congress passed the DMCA on October 28, 1998 as an effort to set a standard of copyright protection on the Internet. ${ }^{24}$

The DMCA limits ISP liability for third-party copyright infringement where the ISP complies with a detailed system of notice and take-down. ${ }^{25}$ It limits liability for four general categories of ISP activity: 1) transitory digital network communications, ${ }^{26}$ 2) system caching, ${ }^{27} 3$ ) information residing on systems or networks at direction of users ${ }^{28}$ and 4 ) information location tools. ${ }^{29}$

had the ability to track, user uploads and downloads. Sega II, Sega Enterprises Ltd. v. MAPHIA... op. cit. 928.

${ }^{24}$ The DMCA was enacted to as part of the US's effort to implement the WIPO treaty, and, while it is comprehensive relative to case law which existed prior to its enactment, some procedural nuances remain to be defined. The DMCA effectively gives legislative backing to the principle laid down in RTC v. Netcom by codifying its ruling that passive automatic acts shall not become grounds for a finding of online copyright infringement. There still exists no international standard for ISPs to follow with respect to copyright infringement. "There is no such thing as an 'international copyright' that will automatically protect an author's writings throughout the entire world. Protection against unauthorized use in a particular country depends, basically, on the national laws of that country." See Soma-Norman: International take-down policy... op. cit. 411.

${ }^{25}$ In its broadest definition, the term "notice" will refer to information an ISP receives that indicates infringement is occurring on one of its systems. "Take-down" will refer to the process whereby an ISP removes or disables access to material stored in or traveling through its networks. See Soma-Norman: ibid.

${ }^{26} 17$ U.S.C.A. $\$ 512$ (a). The first type of safe harbor, transitory digital network communications, can be characterized as "passive conduit" activity. For purposes of this safe harbor, a service provider is defined as "an entity offering the transmission, routing or providing of connections for digital online communications, between or among points specified by a user, of material of the user's choosing, without modification to the content of the material as sent or received."

${ }^{27} 17$ U.S.C.A. § 512(b). The second type of safe harbor, system caching, refers to the process by which ISPs temporarily "store material on a system or network," as part of managing network performance, in order to "reduce network congestion generally" and speed access to popular sites.

${ }^{28} 17$ U.S.C.A. $\$ 512(\mathrm{c})$. The third type of safe harbor activity is storing material for subscribers on a system or network controlled or operated by the service provider. Examples of such storage include providing server space for a user's web site (web hosting) or for a chat room.

${ }^{29} 17$ U.S.C.A. § 512(d). 
In order to qualify for any of these liability limitations, or safe harbors, an ISP must meet the following eligibility requirements. First, it must adopt, reasonably implement and inform subscribers of a policy for terminating repeat copyright infringers. ${ }^{30}$ Second, it must accommodate, and not interfere with, standard technical measures. ${ }^{31}$ In addition to these basic eligibility requirements, ISPs must also meet the specific criteria for each of the four safe harbors. ${ }^{32}$

${ }^{30} 17$ U.S.C.A. $\S 512(\mathrm{i})(1)(\mathrm{A})$.

${ }^{31} 17$ U.S.C.A. \$ 512(i)(1)(B). A standard technical measure is a technology, subject to certain conditions, used by copyright owners to identify or protect copyrighted works. The technical measure must have been developed pursuant to a broad consensus of copyright owners and service providers in an open, fair, voluntary multi-industry standards process, must be available to any person on reasonable and nondiscriminatory terms, and must not impose substantial cost on service providers or their systems and networks. See 17 U.S.C.A. § 512(i) (2).

32 The conditions that apply to first type of carriers are that the If the ISP does not select the recipients of the infringing content, the content must have been transmitted through an automatic technical process 32 and the ISP must not retain intermediate copies of the content for longer than necessary to transmit the information 32 then, it receives immunity from monetary damages. See 17 U.S.C.A. § (a)(2)-(3)

For the Second type of Safe Harbour, the transmission must be initiated by a third party, transmitted through the system to a second user, and stored via automatic processes. See $\S 512(\mathrm{~b})(\mathrm{A})-(\mathrm{C})$. However, unlike protection for transitory communications, this subsection only limits liability for those service providers who, upon notification, "respond expeditiously to remove, or disable access to, the material that is claimed to be infringing." See $\S 512(\mathrm{~b})(\mathrm{E})$

The Third type of safe harbor protects those ISPs that receive no financial benefit "directly attributable to the infringing activity", where the provider has neither the right nor ability to control the activity and where, if properly notified, the ISP suppresses access to the infringing content. See $\S 512(\mathrm{c})(1)(\mathrm{B})-(\mathrm{C})$. However, it does not protect ISPs with actual or constructive knowledge of infringing content who do not, on their own initiative, move quickly to disable access. See § 512(c)(1)(A)(i). However, § 512(c)(1)(C)(2)-(3) additionally details the need for ISPs to provide agents charged with handling infringement notifications on their behalf and enumerates the elements constituting notification sufficient to shift the liability burden back on to the ISP.

Lastly, under $\S 512(d)$, ISPs are granted immunity for the "information location tools" that provide links to "online location[s] containing infringing material or infringing activity ... including a directory, index, reference, pointer, or hypertext link.” But § 512(d)(1)-(3) provides that actual or constructive knowledge of the infringement proves fatal, but $\S(\mathrm{c})$ makes clear, takedown upon notification and the absence of direct financial benefit preserves the immunity. 


\section{A.3. Court's interpretation of the provisions of DMCA-the post DMCA era}

Following the enactment of the DMCA, caselaw quickly began to erode the protections of $\S 512$ 's safe harbors. A brief of some of the cases has been discussed below.

\section{A.3.1. The Napster litigation}

In Napster, ${ }^{33}$ the Ninth Circuit put the question of liability ahead of safe harbor defense consideration in forestalling protection.

Napster owned proprietary "Music Share" software, which it made freely available for Internet users to download. Users could share MP3 music files ${ }^{34}$ with others logged onto the Napster system. Napster allows users to locate and directly exchange MP3 files stored on others' hard drives without paying a fee. ${ }^{35}$ The MP3 file is actually transmitted over the Internet directly between requesting and host users, but the connection could not take place without the Napster server. ${ }^{36}$

The Court assumed that Napster is a "service provider" 37 i.e., Napster transmits information without modifying the content. Nevertheless, the Court held, that Napster's role in the transmission of MP3 files was not entitled to $\S 12$ (a) protection because such transmission does not occur through Napster's system. ${ }^{38}$ In finding vicarious liability likely, despite $\S 512(\mathrm{~m})$ 's "no affirmative duty to police," the Napster court looked upon the peer-to-peer provider's ability to block access to material, or to otherwise terminate infringing users,

${ }^{33}$ A \& M Records, Inc. v. Napster, Inc., op. cit. 239 F.3d 1004 (9th Cir. 2001).

${ }^{34}$ MP3 technology allows for the fast and efficient conversion of compact disc recordings into computer files that may be downloaded over the Internet.

${ }^{35}$ See $A$ \& M Records, Inc. v. Napster, Inc., op. cit. 33.

${ }^{36}$ Id. Napster provides a directory and index of MP3 files that users who are logged on wish to share, but does not store any of the MP3 files on its servers. When the requesting user clicks on the name of an MP3 file listed in Napster's directory, the Napster server routes the request to the "host" user's browser. The host user's browser responds that it either can or cannot supply the file. If the host user can supply the file, the Napster server communicates the host's Internet Protocol (IP) address and routing information to the requesting user's browser.

${ }^{37}$ Under the broader definition of $\S 512(\mathrm{k})(1)(\mathrm{A})$.

${ }^{38} \S 512(a)$ is applicable only to service providers "transmitting, routing or providing connections for, material through a system or network controlled or operated by or for the service provider.” 17 U.S.C.A. § 512(a). See Salow: Liability immunity for internet service providers... op. cit. 11 . 
as evidence that it had the right and ability, and ultimately, the responsibility, to control the infringement. ${ }^{39}$

\section{A.3.2. ALS Scan v. RemarQ communities}

In this case, ${ }^{40}$ users of the ISP RemarQ posted and accessed newsgroup listings containing hundreds of infringing copies of pornographic photos owned by copyright holder ALS Scan. ${ }^{41}$ Technically, ALS Scan failed to comply with $\S 512$ (c) notice and did not specify the "identity of the pictures forming the basis of the copyright claim." 42 Rather, the court based liability on the mere provision of what it considered information sufficient to locate infringing content, reasoning that the safe harbor immunities are "not presumptive, but granted only to 'innocent' service providers who can prove that they do not have actual or constructive notice." 43

${ }^{39}$ Napster, 239 F.3d 1027. "Napster may be vicariously liable when it fails to affirmatively use its ability to patrol its system and preclude access to potentially infringing files listed in its search index ... Napster ... also bears the burden of policing the system within the limits of the system." The Ninth Circuit grounded its vicarious liability analysis of Napster's services by analogy to the Fonovisa swap-meet, in which the ability to block infringers' access to a particular environment for any reason whatsoever is evidence of the right and ability to supervise and direct financial benefit adheres where the availability of infringing material acts as a "draw" for customers. Napster, 239 F.3d 1023 (citing Fonovisa, Inc. v. Cherry Auction, Inc., 76 F.3d 259, 262 (9th Cir. 1996))

${ }^{40}$ ALS Scan, Inc. v. RemarQ Communities, Inc., 239 F.3d 619 (2001). This was the first case where the U.S. Court of Appeals for the Fourth Circuit decided interpreting Title II.

${ }^{41}$ Ibid. 620-621.

${ }^{42}$ See Bretan: Harboring doubts about the efficacy of $\S 512$ immunity under the DMCA. op. cit. 55.

${ }^{43}$ ALS Scan, Inc. v. RemarQ Communities, op. cit. 625. In holding that the copyright owner need not identify infringing content with specificity, ALS Scan suggests ISPs may shoulder a much greater burden than originally contemplated in $\S 512$. See generally Melville B. Nimmer \& David Nimmer, Nimmer on Copyright § 12B.04[B][[4] [discussing notification procedures and the Fourth Circuit's departure in ALS Scan from strict adherence to the statutory requirements under $\S 512(\mathrm{c})]$.

Although this provision requires a copyright owner to give the ISP a detailed notice of infringement, the copyright holder must only provide information that is "reasonably sufficient" to permit the service provider to locate the allegedly infringing material. The court correctly noted that the DMCA requires only "substantial" compliance with § 512(c)'s notice requirements. 43 Since ALS Scan's letter referred RemarQ to two web addresses where RemarQ could find pictures of ALS Scan's models and obtain ALS Scan's copyright information, and virtually all photographs on the web sites identified in the letter were infringing, the letter "substantially complied" with the DMCA. Thus, RemarQ was not entitled to a safe harbor defense. 


\section{A.3.3. The Ellison case}

In this case, a noted science fiction writer brought copyright infringement claims against AOL. ${ }^{44}$ AOL's participation in the Usenet network was functionally identical to RemarQ's activities in ALS Scan except that AOL retained Usenet messages with binary content ${ }^{45}$ on its servers for 'approximately fourteen days. ${ }^{46}$ The court, characterized AOL's participation as a peer in the Usenet message-forwarding system as 'transitory digital network communications' entitled to safe harbor under $\S 512(\mathrm{a}) .^{47}$ Doing so, the court concluded that the threshold requirements of $\S 512(\mathrm{k})(1)(A)$ limiting eligibility for $\S 512(\mathrm{a})$ safe harbor to "entities offering the transmission, routing, or providing of connections for digital online communications, between or among points specified by a user, of material of the user's choosing, without modification to the content of the material as sent or received' merely restated the substantive provisions of $\S 512(\mathrm{a})$, allowing it to bypass an extensive discussion of AOL's status as a $\S 512(\mathrm{k})(1)(\mathrm{A})$ service provider. $^{48}$ The court found that AOL's participation as a peer in Usenet met all the elements of the $§ 512$ (a) safe harbor. ${ }^{49}$

${ }^{44}$ Ellison v. Robertson, 189 F. Supp. 2d 1051, 1054-55 (C.D. Cal. 2002).

${ }^{45}$ Binary content includes graphics files, audio files, motion picture files, and compiled computer programs, among other categories. Many Usenet peer servers retain messages with binary content for shorter periods of time than text messages because they occupy more storage space on the server. See Evans, E.: From the cluetrain to the panopticon: ISP activity characterization and control of internet communications. Michigan Telecommunications and Technology Law Review, 11 (2004) 445.

${ }^{46}$ Ellison v. Robertson, op. cit. 1054.

${ }^{47}$ Ibid. $1067-1068$.

${ }^{48}$ See ibid. 1068.

${ }^{49}$ The court rejected Ellison's claim that the automated filtering rules that AOL had applied--it is the rare ISP that carries every single Usenet newsgroup, and AOL certainly did not--constituted 'selection of the material' under $\$ 512(\mathrm{a})(2)$. See id. 1071 (holding that service provider's selection of newsgroups to carry does not qualify as selection of material under $\S 512(\mathrm{a})(2))$. The court reasoned that if automatic filtering barred ISPs from the § 512(a) safe harbor, ISPs would be forced either to abandon their filtering practices-and therefore carry newsgroups for which there was no end user demand as well as newsgroups devoted to criminal practices like child pornography and prostitution-or abandon their \$512(a) liability protection noting that economic and police power interests support interpretation of $\S 512$ (a) that allows ISPs to engage in automated selection of Usenet traffic for forwarding). See Evans: From the cluetrain to the panopticon... op. cit. 486. 


\section{B. The Australian situation}

Not surprisingly, the case law and clarity of ISP liability for subscriber copyright infringements is less developed in Australia than in the United States. But it can be said that Australia is the only country other than the United States which through various amendments like the Copyright Amendment (Digital Agenda) Act $2000^{50}$ and Australia-United States Free Trade Agreement,${ }^{51}$ there are now clear guidelines for liability of ISPs in Australia.

\section{B.1. Pre digital agenda law situation: The legacy of Telstra v. APRA-strict liability?}

The position in Australia cannot be answered without reference to the case of Telstra Corp. Ltd. v. Australasian Performing Right Ass'n. Ltd. ${ }^{52}$ Although this case does not involve ISPs, the decision holds much significance for them.

An ISP may be subject to strict liability for any copyright infringement committed by its customers even though it had no way of knowing such an infringement had occurred and no chance of preventing it from happening. This is the legacy of the decision by the High Court in Telstra case.

The case involved music, in which APRA owned copyright, played to persons 'on hold' on the telephone. ${ }^{53}$ When the caller who was put on hold used a conventional phone, the High Court held by majority that Telstra had infringed APRA's right to cause the works to be transmitted to the subscribers by a diffusion service. ${ }^{54}$

${ }^{50}$ Copyright Amendment (Digital Agenda) Act, 2000. The Act received Royal Assent on 4 September 2000 and came into force on 4 March 2001. [Hereinafter Referred to as 'CADA'.]

${ }^{51}$ The enabling legislation for the AUSFTA, the U.S. Free Trade Agreement Implementation Act 2004 (Cth), was passed by the Australian Parliament on 13 August 2004 and received Royal Assent on 16 August 2004. The U.S. President, George W. Bush, signed the countervailing legislation, the United States-Australia Free Trade Agreement Implementation Act on 3 August 2004. [Hereinafter referred to as 'AUSFTA'].

52 Intellectual Property Rights, 38 (1997) 294.

${ }^{53}$ Telstra participated in the provision of music on hold in three ways: (1) when a person called a Telstra service centre and was put on hold, s/he was played music; (2) Telstra provided the transmission facilities for other businesses to play music to callers who were on hold; and (3) a person who called a subscriber to the "CustomNet" service heard music if the line was busy. See Paynter, H.-Foreman, R.: Liability of Internet Service Providers for Copyright Infringement. University of NewSouth Wales Law Journal, 4 (1998) 61.

${ }^{54}$ The 'diffusion right'; Copyright Act 1968 (Cth), § 31(1)(a)(v). Conversely, when the caller used a mobile phone, the High Court unanimously held that Telstra had infringed 
Subsequent to this case, APRA based its claim against ISPs on this right. The majority stated that in order to come under the purview of the diffusion right, three elements must be satisfied:

There must be a diffusion service. ${ }^{55}$ The majority held that the unwanted music transferred over telephone lines constituted such a service.

The work must be transmitted to the subscribers of the service. In Telstra, the subscribers to the telephone service were deemed to be subscribers to the diffusion service, because clients who used the telephone service were placed on hold and could receive the music transmission. ${ }^{56}$

The alleged infringer must cause the transmission of the allegedly infringed material. In Telstra, the person operating the service is deemed to be the "person causing work to be transmitted. ${ }^{57}$ The person who undertakes to provide the service to subscribers in agreements with them," is taken to be "the person operating the service." ${ }^{58}$

Therefore, all three elements were satisfied, and the court held Telstra liable for the infringement.

\section{B.2. The Copyright Amendment (Digital Agenda) Act 2000-A new beginning}

In a bid to address the challenges posed to Australian Copyright law by emerging digital technologies, the Australian government passed the Copyright Amendment (Digital Agenda) Act 2000 (Cth), amending the Copyright Act. ${ }^{59}$

The Act implements major reforms to the Act in order to update Australia's copyright regime to take into account the rapid development of new technologies. ${ }^{60}$

APRA's right to broadcast the works. The 'broadcast right'; Copyright Act 1968 (Cth), $\S 31(1)(a)(i v)$. See Telstra, 38 IPR 294, 304, 316, 340.

${ }^{55} \S 26(1)$ provides a diffusion involves "the transmission of the work or other subject matter in the course of a service of distributing broadcast or other matter ... over wires, or other paths provided by a material substance."

${ }_{56}^{56}$ Telstra, Intellectual Property Rights, 303.

${ }^{57}$ Copyright Act 1968 (Cth), § 26(2).

${ }^{58}$ Ibid. § 26(4).

${ }^{59}$ It received royal assent on September 4, 2000, and became applicable as of March 4, 2001.

${ }^{60}$ According to the Australian government's commentary on an exposure draft of the Digital Agenda Act, "the central aim of the reforms introduced by that Act was to ensure that Copyright law continued to promote creative endeavor while allowing reasonable access to Copyright material through the Internet and new communications technology." See Middleton, G.: Australia: Intellectual Property-Copyright: Case Comment. Computer and Telecommunications Law Review, 12 (2006) 2. 


\section{B.2.1. Right of communication to public}

The Act defines communicate as to "make available online or electronically transmit a work or other subject-matter." cable operators, and ISPs have come under the new right to communicate.

\section{B.2.2. Limitation in liability of ISPS}

One of the important aims of the CADA is to limit the liability of ISPs for copyright infringements committed by third parties whilst using their facilities. In determining this, the court after the passing of this Act looks at

- Whether the ISP had the power to prevent the infringement;

- The nature of any relationship between the ISP and the infringer; and

- Whether the ISP took reasonable steps to prevent infringement. ${ }^{62}$

\section{B.2.3. Exclusion for temporary reproduction}

The Act includes exceptions for temporary reproduction or copies of subject matter as part of the technical process of making or receiving a communication. ${ }^{63}$ Since numerous temporary copies of copyright material are made in the course of electronically transmitting material, this exception was necessary for the continued growth of the Internet. ${ }^{64}$ Further, reproductions made in the course of some caching are excluded from liability. ${ }^{65}$

${ }^{61}$ The Copyright Amendment (Digital Agenda) Act 2000, c. 6, § 10(1), sched. 1 (Austl.) (2000).

${ }^{62}$ See $\S \S 36(1 \mathrm{~A})$ and 101(1A). CADA.

${ }^{63} \S \S 43(\mathrm{~A})$ and $111(\mathrm{~A})$ of CADA. Prior to the Digital Agenda Act, there was concern among Internet users in Australia that, because browsing the Internet involves the making of temporary copies of materials which are the subject of copyright in the memory of the user's computer, then Internet users could be liable for infringement of the copyright owner's exclusive right to reproduce those materials. To address this concern, the Digital Agenda Act introduced $\S \S 43 \mathrm{~A}$ and $111 \mathrm{~A}$ into the Copyright Act, which provide that a person does not infringe copyright in online materials by making a temporary reproduction or adaptation of those materials as part of the technical process of making or receiving a communication, provided that the making of the communication does not itself infringe copyright. See Middleton: Australia: Intellectual Property-Copyright... op . cit.

${ }^{64}$ To allow such temporary reproductions, $§ \$ 45$ and 94 make an exception to the copyright owner's exclusive right to reproduce material. Moreover, the exception for temporary copies includes the browsing of copyright material online, thus excluding users from liability for browsing. See Mercurio: Internet Service Provider Liability... op . cit.

${ }^{65}$ Mia Garlick \& Simon Gilchrist, 'The Digital Age: Will Oz Ever Get There' (1999) 3 TeleMedia 6, 79. The general view among legal commentators is that it is unlikely that proxy caching (as opposed to passive or automatic caching) is covered by the temporary reproductions exceptions in $\S \S 43 \mathrm{~A}$ and $111 \mathrm{~A}$ of the Copyright Act, as reproductions of 


\section{B.3. Post digital agenda period}

The provisions in the digital agenda amendment were not complete to perfectly define the liability of ISP due to which further amendments were introduced which brought the Australian Laws in abreast with that of international standards.

\section{B.3.1. The AUSFTA Amendments}

Extensive changes to copyright law have been introduced by the AUSFTA ${ }^{66}$ It introduced new provisions which limit the remedies a court may award for infringement of copyright by an ISP, subject to certain conditions. An ISP may be liable for copyright infringement in relation to something it does itself, and for authorising infringements by people who use its facilities or service.

\section{B.3.1.1. The Safe Harbour Provisions}

The amendments do not affect whether or not an ISP is liable for infringement, but rather the consequences of that liability. The categories of online activities in $\S \S 116 \mathrm{AC}$ to $116 \mathrm{AF}$ of the Copyright Act to which the limitation on remedies under $\S 116 \mathrm{AG}$ apply are similar to the four "safe harbours" of the U.S. DMCA, and are as follows:

Category A: providing facilities for transmitting, routing or providing connections; ${ }^{67}$

Category B: caching by automatic process ${ }^{68}$

Category C: storing material on a ISP system at the direction of a user; ${ }^{69}$ and

Category D: referring users to an online location. ${ }^{70}$

copyright materials made in the course of proxy caching are arguably not temporary, and are not made as part of the technical process of making or receiving a communication. See Middleton: Australia: Intellectual Property-Copyright... op. cit.

${ }^{66}$ Art. 17.11.29 of Chapter 17 of the AUSFTA deals with limitations on liability for "service providers", including providers or operators of facilities for online services or network access such as ISPs. Schedule 9 Part 11 of the AUSFTA implements this Article by inserting new Division 2AA of Part V into the Copyright Act.

${ }^{67} \S 116 \mathrm{AC}$. It reads as "A carriage service provider carries out a Category A activity by providing facilities or services for transmitting, routing or providing connections for copyright material, or the intermediate and transient storage of copyright material in the course of transmission, routing or provision of connections."

${ }^{68} \S 116$ AD. It reads as "A carriage service provider carries out a Category B activity by caching copyright material through an automatic process. The carriage service provider must not manually select the copyright material for caching."

${ }^{69} \S 116$ AE. It reads as "A carriage service provider carries out a Category $\mathrm{C}$ activity by storing, at the direction of a user, copyright material on a system or network controlled or operated by or for the carriage service provider." 
B.3.1.2. Conditions on Limitation of Remedies

In relation to all categories of activities the ISP must provide for termination of accounts of the repeat infringers. ${ }^{71}$ In addition, if there is a relevant industry code in force, the ISP must comply with the relevant provisions of that code. The conditions that must be satisfied for ISPs to enjoy limited liability become more stringent for each category from Category A to Category D. The main provision for limitation under Category A activity is that the transmission must have been initiated by a person other than the ISP while the main conditions for Category $\mathrm{C}$ and Category D activity is that ISPs do not receive a financial benefit directly attributable to the infringing activity and expeditiously remove or disable access to material residing on its network or systems when they obtain actual knowledge of copyright infringement. ${ }^{72}$

\section{B.3.2. The expanding nature of copyright liability through recent court decisions}

In two recent groundbreaking decisions, the Federal Court of Australia considered the liability of intermediaries for online acts of copyright infringement perpetrated by others by authorising those infringing acts.

\section{B.3.2.1. The Cooper Case: Liability for linking}

In the landmark judgment of Universal Music $v$ Cooper, ${ }^{73}$ the Federal Court has held that a person who provides hyperlinks to online material provided by other persons which infringes copyright may be secondarily liable for that copyright infringement.

${ }^{70} \S 116 \mathrm{AF}$. It reads as "A carriage service provider carries out a Category D activity by referring users to an online location using information location tools or technology."

${ }^{71} \S 116 \mathrm{AH}$ lays down the table for conditions for each category of activities.

72 This may be achieved through a notices regime whereby the ISP reacts to effective notices of infringement issued by copyright holders, taking down alleged infringing material, as well as effective counter-notifications by those whose material is the subject of the notice, restoring alleged infringing material. $\S 116$ AI provides that If the ISP, in an action relating to this Division, points to evidence, as prescribed, that suggests that the ISP has complied with a condition, the court must presume, in the absence of evidence to the contrary, that the ISP has complied with the condition.

${ }^{73}$ [2005] F.C.A. 972. This case represents the first time in Australia that the recording industry has accused an ISP of direct involvement in music piracy by allowing its infrastructure to be used for file-trading activities. See Hyland, M.: The ever-expanding nature of Copyright Liability down under. Communications Law, 10 (2005) 157-163, 2005 WL 3752722 (UK). 
Stephen Cooper operated a website which contained hyperlinks to hundreds of MP3 music files stored on remote websites operated by others that could be automatically downloaded free of charge by visitors to Cooper's website by clicking on those hyperlinks. Cooper permitted visitors to his website to create new hyperlinks also.

Universal Music and numerous other copyright owners commenced proceedings against Cooper and Com-Cen for authorising infringement of their copyright in the musical recordings contained in the infringing MP3 files to which Cooper's site linked. ${ }^{74}$

Com-Cen was held liable for authorising the infringing acts which took place via Cooper's website. The Court noted that the safe harbour provisions introduced by the AUSFTA amendments were not in force at the relevant time and do not apply retrospectively. ${ }^{75}$

\section{B.3.2.2 The Kazaa Case: Peer to Peer (P2P) file sharing} In Universal Music Australia Pty Ltd v Sharman License Holdings, ${ }^{76}$ the Federal Court considered for the first time in Australia the liability of providers of

${ }^{74}$ E-Talk Communications Pty Ltd trading as Com-Cen Internet Services ("Com-Cen”) hosted Cooper's website free of charge in exchange for Cooper displaying the "Com-Cen" logo on his website, and provided Cooper with assistance with respect to the establishment and operation of his website. Id.

${ }^{75}$ Even if the safe harbour provisions had been in force, the ISP could not have relied on them because it received a financial benefit from the infringements in the form of free advertising on the website, the ISP used to receive financial benefit and because it failed to take action against the website proprietor despite knowing that infringements were taking place. Although Com-Cen denied having knowledge of the content of Cooper's website, the court found that this was unlikely, as the free hosting arrangement which Com-Cen had negotiated with Cooper was likely to be based on the fact that Com-Cen believed it was a high-traffic website, and would therefore provide valuable advertising exposure. Further, it is likely that Com-Cen would have visited Cooper's website to ensure that Cooper had added the Com-Cen logo to his website, as agreed. Com-Cen did not take steps to prevent the infringing acts by refusing to host Cooper's website, which was a reasonable step that it could have taken to prevent or avoid the infringing acts. See Williams, Micheals: “An overview of the current legal framework and predictions about the future of online liability in Australia"; Accessed from http://www.copyright.asn.au/pdf/powerpoint/f07n01williamsppt.pdf

${ }^{76}$ [2005] F.C.A. 1242. In the decision delivered on 5 September 2005, the Federal Court held that Sharman Networks Ltd.which controlled had authorized infringement of copyright by users of its file-sharing software. See Baulch, Libby: "Major Copyright Reforms and software IPR protection in Australia" Accessed from http://www.copyright. org.au/pdf/acc/articles_pdf/a06n17.pdf 
peer-to-peer files-sharing networks for copyright infringements perpetrated by users of their networks.

The applicants brought an action against Sharman Networks Limited, which controlled the Kazaa peer to peer file sharing system, facilitated by the Kazaa Media Desktop (KMD)software program which users could download free of charge from the Kazaa website. Kazaa generated revenue from streaming advertising to users of the KMD. Users of the KMD could access "blue files", which are not subject to any arrangement with the copyright holders in those files, and "gold files", which are licensed files made available by arrangement with the relevant copyright owners.. ${ }^{77}$

The ISP was held liable for Copyright Infringement. Wilcox J emphasized that a number of factors supported this finding. First, the court held that respondents had long known that the Kazaa system was widely used for the sharing of copyright files, and that the measures that they had adopted were "ineffective to prevent copyright infringements by users." Second, the respondents had failed to take technical measures that would curtail the sharing of copyright files. ${ }^{78}$

\footnotetext{
${ }^{77}$ The Kazaa website contained notices on each page that the respondents did not condone activities that infringe copyright. Kazaa users also had to enter into a browse-wrap end-user licence agreement which made it a condition of use of the KMD that users agreed not to use the software to infringe the intellectual property rights of others, and warning users of their potential liability if they infringed copyright or other intellectual property rights of others. However, the Kazaa website also linked to a website headed "Join the Revolution", which criticized the opposition of record and movie companies to peer-topeer networks, and encouraged the use of peer-to-peer applications as being beneficial to everyone by providing lower prices, unlimited catalogues "and more". See Middleton: Australia: Intellectual Property-Copyright... op. cit.

${ }^{78}$ Ibid. The Court observed: "It is in the respondents' financial interest to maximize, not to minimize, music file-sharing." Also Wilcox J further observed that "far from taking steps that are likely effectively to curtail copyright file-sharing, Sharman Networks and Altnet have included on the Kazaa Web site exhortations to users to increase their filesharing and a Web page headed 'Join the Revolution' that criticizes record companies for opposing peer-to-peer file-sharing." He further noted that this Web campaign would "encourage visitors to think it 'cool' to defy the record companies by ignoring copyright constraints." The Court also ordered that the Kazaa Internet file-sharing system could continue to operate but only if within two months it was modified to include technology to prevent copyright infringement.
} 
As a result of the decision, there is a concern that the burden of enforcement may be shifted away from the rights holder and onto unrelated third parties such as ISPs. ${ }^{79}$

Kaaza appealed against this decision but, on 27 July 2006, the parties announced that the action had been settled. ${ }^{80}$

\section{The European approach}

The European approach towards ISP liability is primarily dealt with two Directives i.e., the EU Copyright Directive ${ }^{81}$ and the e-commerce Directive, which already has been implemented by a number of European Countries as part of their national legislation. Although EU directives do not have the force of law in EU member countries, they do require EU member countries to amend their own laws to the extent necessary to conform to the Directives' intended results. $^{82}$

\section{C.1. The copyright directive}

This Directive sets out certain limitation on the liability of ISPs. Article 5(1) provides for an exception from liability for copyright infringement, where the reproduction is transient or incidental when the transient copies are an integral and essential part of a technological process whose sole purpose is to enable a transmission in a network between third parties by an intermediary or a lawful use of a work or other subject-matter to be made; and they have no independent economic significance. The net effect of this is that ISP's will not be required

${ }^{79}$ Ibid. The court ordered that the respondents could continue to operate the Kazaa network without liability for authorization infringement if they implemented a mandatory keyword filtering system in all new versions of the KMD, and imposed maximum pressure on existing Kazaa users to upgrade their existing KMD software to a version which included the keyword filtering system by the use of dialogue boxes which could not closed until the user upgraded.

${ }^{80}$ The settlement also applied to legal actions relating to Kazaa in the US. The settlement agreement includes an undertaking by the Kazaa operators to introduce filtering technology to block access to infringing music files.

${ }^{81}$ Directive 2001/29/EC of the European Parliament and of the Counsel of May 22, 2001 on the harmonization of certain aspects of Copyright and related rights in the information society.

${ }^{82}$ Scherzer, H.: European Copyright Directives Ushers in Era of Harmony, Change. (2001) 226 New York Law Journal, 113 (2001) 73. 
to seek consent, or to pay for transient copies made across their networks as part of the transmission process.

Additionally, the EU Copyright Directives offers numerous optional exemptions that member countries may enact so as to limit ISP liability under their own laws. ${ }^{83}$

\section{C.2. The EU E-Commerce Directive}

The EU E-Commerce Directive offers insight into the willingness of EU member countries to address the liabilities of ISPs as "service providers" of "information society services", ${ }^{84}$ applies to ISPs established within the European Union. ${ }^{85}$ The key areas of the directive relating to ISP liability are the 'mere conduit' exception provision, which provides that ISP's are not liable for information transmitted on their networks provided they do not initiate the transmission, do not select the receivers of the transmission, and do not select or modify the information in the transmission, ${ }^{86}$ Caching provision, where ISP will not be held liable for the automatic, intermediate, and temporary storage of information that is carried out for the sole purpose of

${ }^{83}$ Ch. II Art 5, 2-5 of the Directive. Although the EU Copyright Directive does not contain any provision in favour of copyright owners that is similar to the notice and takedown procedure in the DMCA, it requires EU member states to provide and apply "effective, proportionate and dissuasive" sanctions and remedies for copyright holders in the infringement context. See Ch. IV, Art. 8, 1 of the Directive.

${ }^{84}$ Directive 2000/31/EC of the European Union and of the counsel of June 8, 2000 on certain legal aspects of informations society services, in particular electronic commerce, in the internal market. ("Directive on Electronic Commerce") ("EU E-Commerce Directive"). Under this directive intermediaries are referred s "Information Society Services". It is defined as "Any service normally provided for remuneration, at a distance, by electronic means and at the individual's request of a recipient of a service". This definition is drafted in such a way as to include a wide range of intermediaries including content providers and traditional Internet Service Providers.

${ }^{85}$ Fancher, C.-Dunn, G. H.: The Trend towards limited internet service provider (ISP) liability for third party copyright infringement in the internet: A United States and global perspective. Business Law International, 4 (2002) 152.

${ }^{86}$ Art 12 of the Directive. Those on-line intermediaries found to meet these three conditions are considered mere conduits, and will not be held responsible for illegal information put on the network by third parties. In other words, in so far as on-line intermediaries fulfill the necessary conditions to be qualified as mere conduits, the standard of liability is "no liability". See Julia-Barcelo, R.: On-line intermediary liability issues: comparing E.U. and U.S. legal frameworks. European Intellectual Property Review, 22 (2000) 105-119, 109. 
making the onward transmission of the information more efficient; ${ }^{87}$ Hosting provision, where ISPs which provide storage space on web servers to thirdparty users, an act known as "hosting", benefit from a limitation of their liability for acts related to such storage. ${ }^{88}$

\section{The Asian viewpoint}

\section{D.1. Singapore:Leading the Asian provisions}

Singapore has enacted various legislations dealing with ISP liability from time to time. The Singapore Electronic Transactions Act, 1998 and U.S. Singapore Free Trade Agreement ${ }^{89}$ are a step ahead in this regard.

\section{D.1.1. Singapore's Electronic Transactions Act 1998}

In 1998 the Singapore Parliament adopted very clear measures aimed at insulating ISP's from both civil and criminal liability under $\S 10$ of the Electronic Transactions Act 1998. This provision provides that an ISP shall not be subject to any civil or criminal liability in the form of electronic records to which that ISP merely provides access. ${ }^{90}$ This immunity is granted only if the liability is founded on the making, publication, dissemination or distribution of such materials or any statement made in such material ${ }^{91}$ or the infringement of any rights subsisting in or in relation to such material. ${ }^{92}$ The importance of this

${ }^{87}$ Art 13 of the Directive provides that this immunity applies where the ISP does not modify the cached information, complies with access conditions in relation to the information, complies with any rules in respect of updating the information and does not interfere with the lawful use of technology with the intention of obtaining data on the use of the cached content. Art 13 of the Directive. See Sutter, Gavin; "FE/HE Institutions and Liability for Third Party Provided Content"; Accessed from http://www.jisclegal.ac.uk/ publications/thirdpartycontent.htm

${ }^{88}$ See Art. 14 of the Directive. An ISP will not be liable for hosting information, provided they do not have actual knowledge that the activity is illegal and, upon obtaining such knowledge, act quickly to remove it.

${ }^{89}$ Hereinafter referred to as 'USSFTA'.

${ }^{90} \S 10(1)$. For the purposes of this section-"provides access", in relation to third-party material, means the provision of the necessary technical means by which third-party material may be accessed and includes the automatic and temporary storage of the third-party material for the purpose of providing access; "third-party", in relation to a network service provider, means a person over whom the provider has no effective control.

${ }^{91} \S 10(1)(a)$.

${ }^{92} \S 10(1)$ (b). This exemption from liability is potentially very powerful. It is not even conditional upon lack of knowledge on the part of the service provider. Hence it will apply 
piece of legislation cannot be overstated, because prior to 1998 the prospect of ISP liability under the laws of Singapore was a real one, even for those ISP's that took no measures at all to patrol traffic on their systems.

\section{D.1.2. The Singapore Copyright (amendment) Act 1999}

This amendment ${ }^{93}$ provided that when the ISP makes an electronic copy of the copyright material available on the network, it cannot be liable for infringement if it is made available in the course of providing connections to the copy, in the storage, transmission, routing, or provision of connections is done at the direction of a user of the network without any deliberate modification of its contents by the ISP. ${ }^{94}$

\section{D.1.3. U.S. Singapore Free Trade Agreement}

The USSFTA Implementation Act was implemented by both countries on January $1,2004 .^{95}$ This agreement provides for limited liability for ISPs, reflecting the balance struck in the U.S. DMCA between legitimate ISP activity and the infringement of copyrights. ${ }^{96}$ The courts will be precluded from granting monetary relief for any copyright infringement by ISPs in the course of hosting

even if a service provider knows that a certain web-site has a lot of unlicensed, pirated software for download, and that many of the service provider's subscribers access that "warez" web-site.

${ }^{93}$ In Singapore, the Registry of Trade Marks and Patents formed an Electronic Commerce Committee in 1998 to comprehensively study the issues involved and provide suggestions for dealing with these issues. In later part of 1999, the Singapore Parliament incorporated these suggestions in a Bill and enacted the Copyright (Amendment) Bill 1999 incorporating it into the Copyright Act.

${ }^{94} \S 193 \mathrm{C}(1)$. However, if the copyright owner provides an ISP with a statutory declaration expressing his belief of the occurrence of a copyright infringement, then it is not exempt from liability for making the material available on the network under $\S 193 C(1)$ of the Copyright (Amendment) Act. This declaration from the copyright owner must outline the reasons underlying the copyright owner's allegations of copyright infringement. The ISP on receiving such notice has the responsibility of removing the copy from the network or disabling access to the material on the network. If the ISP fails to do this in a reasonable time, the Network Service Provider is liable.

${ }^{95}$ The US-Singapore Free Trade Agreement was signed May 6, 2003 and ratified by the US House of Representatives on July 24, 2003 by a vote of 272-155. The US Senate ratified the bill on July 31, 2003 by a vote of 66-32. President George W. Bush signed into law the United States-Singapore Free Trade Agreement Implementation Act on September 3, 2003.

${ }^{96}$ See Report for Congress on US-Singapore Free Trade Agreement; Accessed from http://digital.library.unt.edu/govdocs/crs/permalink/meta-crs-5582:1 
and transmitting material. However, this immunity applies only if ISPs comply with certain administrative requirements such as the taking down of infringing content once they have been notified by the copyright owner in writing, and the putting back of that same content on counter-notice by the website owner.

\section{D.2. The Indian stand}

The Copyright Act, 1957 was obviously drafted in complete oblivion of the phenomenon called the Internet. Even after its amendments in 1994 and 1999 it does not contain any express provision for determining or limiting ISP liability.

\section{D.2.1. ISP Liability Under Information Technology Act, 2000}

The provisions relating to the ISPs are specifically legislated in the IT Act, 2000 where an ISP is referred to as Network service provider and Explanation (a) to $\S 79$ defines it as: "Network service provider" means an intermediary. ${ }^{97}$ This provision exempts ISPs from liability if they can prove that they had no knowledge of the occurrence of the alleged act, and that they had taken due diligence to prevent a violation. ${ }^{98}$ The liability of ISPs could arise in a number of ways under different statutes. The liability could be criminal or civil in nature depending on various factors. ${ }^{99}$ The idea is that the liability of an ISP for his action or omission be first determined in accordance with the statute under

\footnotetext{
${ }^{97}$ Intermediary has been defined under $\S 2(w)$ as: "intermediary" with respect to any particular electronic message means any person who on behalf of another person receives, stores or transmits that message or provides any service with respect to that message.

${ }^{98}$ See Information Technology Act 2000 § 79. However, the existing provision does not clearly prescribe liability limits of service providers. For example, if a person makes a representation to a service provider claiming copyright on the material available on the network, will the service provider be liable if he fails to take steps within a reasonable time to remove the infringing material from the network? If the service provider fails to prevent infringement of copyright in the above circumstances, is the plea of not having knowledge of infringement still available to him? If the service provider removes the material from the network in pursuance to the representation made by a person which later on proves false, will the service provider be liable to the person whose material has been removed?

${ }^{99}$ It is impractical to define the liability of ISPs which could arise in various forms at one place. Equally impractical could be to amend all our laws, which could hold ISPs liable, in order to limit their liability. The latter has not been attempted in any of the Indian legislations including the Copyright Act, 1957 till now. The IT Act, 2000 does not attempt the former but just seeks to create a filtering mechanism for determining the liability of ISPs.
} 
which it arises and then if at all the ISP is held liable, his liability again be filtered through $\S 79$ of the IT Act. ${ }^{100}$

\section{Proposal for international standard guidelines and conclusion}

As courts and legislators continue to mold ISP liability standards, it is crucial that developments in substantive copyright law amendments occur alongside international agreement to create and adopt standardized procedures so that copyright holders, ISPs, and alleged infringers can easily follow where copyright infringement occurs on an international scale.

This expansive growth of internet demands creation of a viable framework of international procedural standards that equip copyright holders and alleged infringers with a practicable means of contacting one another and resolving conflicts on a temporary interim basis.

If the U.S.'s recent legislative effort, the DMCA, is any indication of how other countries will treat ISP copyright liability for third-party infringement, then copyright will be limited by broad substantive legal exemptions for ISPs, leaving them with potentially divergent procedural standards to follow in jurisdictions where they are forced to guard their copyrights. ${ }^{101}$

Designing an international notice/take-down standard requires consideration of the sovereignty of any given country's individual substantive copyright law. While it is impractical to include every potential caveat of individual laws in each country, it is feasible to generate a set of procedural guidelines applicable to all. Having examined both case law and legislative efforts in the U.S. and abroad, four viable behavioral elements appear to be essential: 1) designation of an agent to receive notice of infringement, 2) presumption of jurisdiction over the matter in the state where the ISP resides and accepts notice, but not necessarily in the jurisdiction where the copyright owner resides, 3) expeditious take-down pending formal resolution by a judicial body, and, 4) reasonable restoration of material or access to material where legitimate counter notification is presented to the ISP.

WIPO as a guardian and promoter of international property rights to implement international notice and take-down policy guidelines. WIPO is suitable to

${ }^{100}$ An illustration of this can be of a situation where an ISP is accused of illegally distributing pirated copies of music, then his liability be first determined under $\S 51$ (a)(ii) and $\S 63$ of the Copyright Act, 1957. If the ISP is found liable then his liability again be tested on the touchstone of $\S 79$ of the IT Act, 2000.

${ }^{101}$ See Soma-Norman: International take-down policy... op. cit. 
address the complex issues that raise when copyright infringement spans international borders. Further support for WIPO stems from its position on multijurisdictional conflicts.

Another appropropriate international organization for implementing international take down standards of conduct in copyright infringement claims could be the World Trade Organization ${ }^{102}$ It creates no new substantive rights, but seeks only to enforce compliance with existing substantive rights of member countries. Without having to interpret or select the law applicable to any given copyright infringement claim that occurs on an international basis, the WTO can effectively implement procedural guidelines to at minimum place parties to any controversy in a position where they can take the next step of litigating the matter. This relieves the WTO from making any jurisdictional determinations, or concluding which party should prevail.

International standards for copyright protection must occur in the spirit of freely disseminating information and encouraging the broadest communication possible. International procedural guidelines implemented by the WTO and WIPO would strike a balance between the interests of copyright holders, ISPs, and alleged infringers without having to overcome the impracticable burden of creating uniform, substantive global copyrights.

The internet is the future and ISPs are the gateway. Let the world come together and protect it from being dragged into gratuitous litigations.

${ }^{102}$ The World Trade Organization (Hereinafter referred to as 'WTO') is the only global international organization dealing with the rules of trade between nations. At its heart are the WTO agreements, negotiated and signed by the bulk of the world's trading nations and ratified in their parliaments. The goal is to help producers of goods and services, exporters, and importers conduct their business. The World Trade Organization was created as part of the General Agreement on Tariffs and Trade (GATT) revision signed April 15, 1994. As part of the 1994 revision of the GATT, the Agreement on Trade-Related Aspects of Intellectual Property Rights,), established the WTO and created an enforcement structure to safeguard international intellectual property rights. See Soma-Norman: International takedown policy... op. cit. 